\title{
Pemanfatan Nutrisi pada Sapi Bali Betina Afkir yang Diberi Pakan Komplit Fermentasi Berbasis Daun Gamal dengan Level Energi Berbeda
}

\author{
M. M. Sadipun ${ }^{\mathrm{a}}$, I Gusti N. Jelantik ${ }^{\mathrm{a}}$, dan M. L. Mullik . \\ ${ }^{a}$ Fakultas Peternakan, Universitas Nusa Cendana., Jl. Adi Sucipto, Kupang, Indonesia.
}

\section{Article Info}

Article history:

Received 13 Agustus 2016

Received in revised form 13 September 2016 Accepted 21 September 2016

Keywords:

Gliricidia sepium

Pakan Komplit

Fermentasi

\begin{abstract}
Abstrak
Penelitian ini bertujuan untuk menilai respon kenaikan berat badan sapi bali yang diberi pakan komplit fermentasi berbasis daun gamal (Gliricidia sepium) yang mengandung tingkat tambahan energi metabolis sebesar 7 MJ. Rancangan penelitian menggunakan RAL dengan dua puluh satu ekor sapi Bali (berumur 5-8 tahun dan berat badan 174,8 - 188,9 kg) yang terdiri dari tiga perlakuan dan tujuh ulangan. Pemberian pakan berlangsung selama 12 minggu. Hasil penelitian menunjukkan bahwa pemberian pakan komplit fermentasi berbasis daun gamal dengan level energi metabolis berbeda (EM $7 \mathrm{MJ} / \mathrm{Kg}$ BK, EM $8 \mathrm{MJ} / \mathrm{Kg}$ BK dan EM $9 \mathrm{MJ} / \mathrm{Kg} \mathrm{BK}$ ) tidak mempengaruhi konsumsi dan kecernaan protein kasar, energy metabolis, konsumsi bahan kering tercerna, konsumsi nutrien kemudian juga cenderung menin gkatkan PBB sapi Bali betina afkir yang digemukan dengan protein kasar 12,3\%, dari pakan EM $8 \mathrm{MJ} / \mathrm{kgBK}$ menjadi EM $9 \mathrm{MJ} / \mathrm{kgBK}$ cenderung meningkatkan PBBHnya sebesar 0,63-0,75kg/hari. @2016 dipublikasikan oleh JAS.
\end{abstract}

\section{Pendahuluan}

Provinsi NTT mempunyai luasan padang penggembalaan yang mencapai 832,228 ha dan sekitar 2,4 juta lahan kering yang dapat diperuntukkan untuk pengembangan ternak sapi dengan tingkat pemanfaatan $54,62 \%$ (Dinas Peternakan NTT, 2013). Namun demikian, kontribusi NTT terhadap pemenuhan daging nasional dan peningkatan kesejahteraan masyarakat belum optima terkendala oleh rendahnya produktivitas ternak sapi di daerah ini. (Mullik dan Jelantik, 2009) mencatat bahwa hanya 9-12\% dari populasi tersebut dapat diantar-pulaukan dan dipotong untuk memenuhi kebutuhan daging di daerah tersebut. Jelantik et al., (2009) mengemukakan bahwa salah satu faktor yang memberikan kontribusi tertinggi terhadap rendahnya produktivitas ternak sapi di daerah ini adalah tingginya proporsi sapi betina afkir (tua) yaitu sekitar $32 \%$ berumur lebih dari 8 tahun yang masih berada dalam populasi betina dewasa pada peternakan rakyat. Hal ini akan berdampak pada menurunnya angka kelahiran dan meningkatnya angka kematian pedet. Faktor yang menyebabkan menetapnya betina afkir tersebut dalam populasi adalah adanya preference pemotongan betina produktif untuk memenuhi kebutuhan daging secara lokal. Hal in disebabkan betina afkir dianggap sulit untuk digemukkan dan daging yang dihasilkan berkualitas rendah, tidak layak untuk konsumsi dan hanya dapa diperuntukkan untuk produk olahan. Dengan demikian hasil penelitian (Jelantik et al., 2012) menunjukkan bahwa sapi Bali betina afkir yang digemukkan dengan kandungan protein kasar pakan mencapai $12 \%$ PBBHnya mencapai $0,6 \mathrm{~kg}$ per hari.

Beberapa data penelitian menunjukkan bahwa pakan berenergi rendah dan/atau berprotein rendah akan berpengaruh negatif terhadap ternak. Namun hingga kini belum diketahui berapa besar level energi pakan yang dibutuhkan untuk penggemukan sapi betina afkir. Penelitian ini bertujuan untuk menilai respon kenaikan berat badan sapi bali yang diberi pakan komplit fermentasi berbasis daun gamal (Gliricidia sepium) yang mengandung tingkat tambahan energi.

\section{Metode}

Penelitian ini menggunakan 21 ekor ternak sapi Bali betina afkir dengan skor kondisi tubuh 2 dan kisaran berat badan 174,82-188,93kg atau rata-rata 180,81 $\mathrm{kg}$ dan kisaran umur 5-8 tahun. Dibagi 3 kelompok untuk mendapatkan 3 perlakuan berupa EM7 : Pakan komplit fermentasi protein kasar 12,3\% dan energi $7 \mathrm{MJ} / \mathrm{kg}$ BK, EM8 : Pakan komplit fermentasi protein kasar 12,3\% dan energi $8 \mathrm{MJ} / \mathrm{kg}$ BK dan EM9: Pakan komplit fermentasi protein kasar 12,3\% dan energi $9 \mathrm{MJ} / \mathrm{kg} \mathrm{BK}$. Ketiga jenis ransum tersebut difermentasi selama 14 hari menggunakan EM4 dengan perkiraan kadar air 35-50\% dalam wadah plastik dengan kapasitas sekitar 50kg. Sebelum diberikan terlebih dahulu pakan dianginanginkan selama 2 jam. Kandang berupa kandang individu tipe tunggal lengkap dengan tempat pakan dan air minum. Penelitian ini mengikuti pola Rancangan Acak Lengkap (RAL) dengan 3 perlakuan dan 7 ulangan. Parameter yang dihitung adalah konsumsi dan kecernaan serta PBB dan konversi pakan.

Tabel 1. Komposisi Bahan Pakan Penelitian

\begin{tabular}{llll}
\hline \multirow{2}{*}{ Komponen Ransum (\% BK) } & \multicolumn{3}{c}{ Perlakuan } \\
\cline { 2 - 4 } & EM7 & EM8 & EM9 \\
\hline Jerami padi & 40 & 20 & 10 \\
Daun gamal & 10 & 15 & 10 \\
Dedak padi & 25 & 25 & 19,8 \\
Jagung giling & 5 & 15 & 25 \\
Putak & 18,5 & 24 & 34 \\
Urea & 1,5 & 1,1 & 1,4 \\
Mineral mix & 1 & 1 & 1 \\
Garam & 1 & 1 & 1 \\
\hline Kandungan PK (\%) & 12,3 & 12,3 & 12,3 \\
Kandungan EM (MJ/kg BK) & 7,34 & 8,38 & 9,36 \\
\hline
\end{tabular}

Tabel 2. Komposisi dan Kandungan Kimia Pakan Komplit Fermentasi dengan $12 \%$ PK dan EM 7, 8, 9 MJ/kg BK

\begin{tabular}{lllllrr}
\hline \multicolumn{1}{c}{ Bahan } & BK $(\%)$ & BO $(\% \mathrm{BK})$ & PK $(\% \mathrm{BK})$ & SK $(\% \mathrm{BK})$ & $\begin{array}{r}\text { BETN } \\
(\% \mathrm{BK})\end{array}$ & $\begin{array}{r}\text { EM } \\
(\mathrm{MJ})\end{array}$ \\
\hline Jagung giling & 89.48 & 97.97 & 10.91 & 1.18 & 79.89 & 18.71 \\
Dedak & 89.29 & 96.11 & 17.27 & 7.23 & 66.44 & 18.69 \\
Putak & 87.01 & 97.78 & 3.98 & 3.28 & 87.41 & 17.71 \\
Jerami Padi & 100 & - & 5,31 & 35,1 & 36,68 & - \\
Daun Gamal & 21,9 & $50-65$ & 23,11 & 38,49 & 17,37 & - \\
\hline
\end{tabular}

\section{Hasil dan Pembahasan}

Pengaruh pemberian pakan komplit berbasis daun gamal (Gliricidia sepium) yang mengandung energi metabolisme sebesar $7 \mathrm{MJ} / \mathrm{kg}$ (EM7), $8 \mathrm{MJ} / \mathrm{kg}$ (EM8) dan $9 \mathrm{MJ} / \mathrm{kg}$ (EM9) Terhadap Konsumsi Ransum sapi bali betina afkir seperti tersaji pada Tabel 3 .

Tabel 3. Pengaruh Pemberian Pakan Komplit Fermentasi Berbasis Daun Gamal Yang Mengandung Energi Metabolis Sebesar $7 \mathrm{MJ} / \mathrm{kg}$ (EM7), $8 \mathrm{MJ} / \mathrm{kg}$ (EM8) dan $9 \mathrm{MJ} / \mathrm{kg}$ (EM9) Terhadap Konsumsi Ransum

\begin{tabular}{|c|c|c|c|c|c|}
\hline \multirow{2}{*}{ Parameter } & \multicolumn{3}{|c|}{ Perlakuan Level Energi } & \multirow{2}{*}{ SEM } & \multirow{2}{*}{$\mathrm{P}$} \\
\hline & EM7 & EM8 & EM9 & & \\
\hline \multicolumn{6}{|l|}{ Konsumsi (kg/hr) } \\
\hline Bahan kering & 6,18 & 6,03 & 6,27 & 0.18 & 0.11 \\
\hline Bahan organik & 5,36 & 5,52 & 5,56 & 0.16 & 0.86 \\
\hline Protein kasar & 0,76 & 0,74 & 0,77 & 0.02 & 0.86 \\
\hline Lemak kasar & $0,37^{\mathrm{a}}$ & $0,46^{\mathrm{b}}$ & $0,52^{\mathrm{b}}$ & 0.02 & 0.00 \\
\hline Serat kasar & 1,31 & 1,17 & 1,10 & 0.04 & 0.86 \\
\hline Karbohidrat & 4,44 & 4,40 & 4,34 & 0.13 & 0.86 \\
\hline BETN & 3,12 & 3,22 & 3,24 & 0.09 & 0.86 \\
\hline Energi metabolis (MJ) & $43,26^{\mathrm{a}}$ & $48,23^{\mathrm{a}}$ & $56,50^{\mathrm{b}}$ & 1.53 & 0.01 \\
\hline \multicolumn{6}{|l|}{ Konsumsi (\%BB) } \\
\hline Bahan Kering & 3,58 & 3,43 & 3,35 & 0.14 & 0.79 \\
\hline Bahan organic & 3,11 & 3,13 & 2,99 & 0.12 & 0.79 \\
\hline Protein kasar & 0,44 & 0,42 & 0,41 & 0.02 & 0.78 \\
\hline Lemak kasar & $0,21^{\mathrm{a}}$ & $0,26^{\mathrm{ab}}$ & $0,28^{\mathrm{b}}$ & 0.02 & 0.04 \\
\hline Serat kasar & $0,76^{\mathrm{b}}$ & $0,67^{\mathrm{ab}}$ & $0,59^{\mathrm{a}}$ & 0.03 & 0.79 \\
\hline Karbohidrat & 2,57 & 2,50 & 2,33 & 0.10 & 0.79 \\
\hline BETN & 1,81 & 1,83 & 1,74 & 0.07 & 0.79 \\
\hline Energi metabolis (MJ) & 25,08 & 27,44 & 30,14 & 1.11 & 0.21 \\
\hline \multicolumn{6}{|l|}{ Konsumsi (g/kgBB0,75) } \\
\hline Bahan Kering & 129,63 & 124,75 & 123,79 & 4.51 & 0.85 \\
\hline Bahan organic & 112,46 & 114,05 & 110,27 & 4.01 & 0.99 \\
\hline Protein kasar & 16,00 & 15,40 & 15,28 & 0.56 & 0.85 \\
\hline Lemak kasar & $7,65^{\mathrm{a}}$ & $9,53^{\mathrm{b}}$ & $10,27^{\mathrm{b}}$ & 0.34 & 0.01 \\
\hline Serat kasar & $27,53^{\mathrm{a}}$ & $24,21^{\mathrm{ab}}$ & $21,73^{\mathrm{b}}$ & 0.87 & 0.05 \\
\hline Karbohidrat & 93,04 & 90,94 & 85,98 & 3.21 & 0.73 \\
\hline BETN & 65,50 & 66,71 & 64,25 & 2.34 & 0.99 \\
\hline Energi metabolis (MJ) & $907,45^{\mathrm{a}}$ & $997,96^{\mathrm{ab}}$ & $1114,15^{b}$ & 36.60 & 0.10 \\
\hline
\end{tabular}

Jika dibandingkan dengan penelitian lain maka tingginya konsumsi pakan pada ternak sapi Bali betina afkir yang digunakan dalam penelitian ini dapat disebabkan oleh beberapa faktor yaitu kapasitas rumen (Jelantik et al., 2010), tingkat produksi (Paraksasi, 1999) dan status fisiologis (Preston dan Leng, 1987). Hasil analisis sidik ragam menunjukkan bahwa konsumsi bahan kering dan nutrisi lainnya (Bahan organik, Protein kasar, Serat kasar, BETN dan Energi Metabolis) tidak berbeda nyata (P.>0.05). Tercatat konsumsi serat kasar dan lemak kasar yang berpengaruh nyata $(\mathrm{P}<0.05)$ ketika dikonversi dalam berat badan metabolis $(\mathrm{g} / \mathrm{kgBB} 0,75)$ cenderung menurun seiring dengan peningkatan kandungan energi pakan. Konsumsi nutrisi serat kasar menurun dari 27,53 $\mathrm{g} / \mathrm{kgBB} 0,75$ pada pakan EM7 MJ menjadi $21,73 \mathrm{~g} / \mathrm{kgBB} 0,75$ pada EM9 MJ. Sementara hasil uji lanjut Duncan menunjukan bahwa pemberian ransum EM7 
MJ/kg BK berbeda EM9 MJ/kg BK sementara EM8 MJ/kg BK tidak berbeda dengan EM7 MJ/kg BK dan EM9 MJ/kg BK.

Terdapat beberapa hal yang menjadi alasan untuk konsumsi nutrisi (bahan organik, protein kasar, serat kasar, BETN dan energi metabolis) pada ternak yang diberikan pakan komplit fermentasi berbasis daun gamal dengan EM lebih tinggi. Pertama adalah fermentasi pakan telah berdampak pada peningkatan potensi fermentasi di dalam rumen. Potensi fermentasi dapat dipengaruhi oleh kandungan serat kasar dalam ransum dan kandungan karbohidrat mudah dicerna. Kandungan serat kasar pada ransum meningkat seiring dengan penurunan nilai energi. Seharusnya semakin tinggi kandungan serat kasar dalam ransum maka konsumsi akan semakin menurun karena kapasitas fisik rumen yang membatasi. Begitu pula dengan peningkatan komposisi jagung dalam ransum yang merupakan karbohidrat mudah tercerna tidak mempengaruhi konsumsi ternak sapi Bali betina afkir. Hal ini dikarenakan bahan pakan yang digunakan merupakan pakan fermentasi dimana jerami padi yang digunakan sudah difermentasi menggunakan urea dan EM4. Proses fermentasi yang dilakukan dapat mengubah lignoselulosa menjadi senyawa yang lebih sederhana melalui dipolimerisasi. (Asngad, 2005) yang menyatakan bahwa teknologi fermentasi yang dilakukan pada jerami padi bila dilakukan secara baik mampu merenggangkan ikatan ligninselulosa dan lignohemiselulosa pada jerami padi, sehingga selulosa bisa dimanfaatkan. Kedua adalah adanya perbedaan mekanisme kontrol konsumsi pada ternak yang diberikan ransum dengan EM yang berbeda. Pada ternak yang mengkonsumsi ransum dengan level EM7 oleh karena kandungan serat yang tinggi, konsumsi dikontrol oleh kapasitas fisik rumen. Tingkat konsumsi yang diperoleh pada EM7 telah mencapai kapasitas rumen ternak tersebut (konsumsi maksimal). Sementara itu, pada ternak yang mengkonsumsi EM yang lebih tinggi (8 MJ dan 9 MJ) ternak sebenarnya mempunyai kapasitas mengkonsumsi yang lebih tinggi lagi karena kandungan serat ransum yang lebih rendah (rumen fill lebih rendah). Namun pada kenyataannya konsumsinya tidak lebih tinggi. Fenomena ini dapat terjadi ketika konsumsi dikontrol oleh mekanisme metabolik, artinya ternak berhenti makan ketika asupan nutrisi sudah memenuhi kebutuhan walaupun rumen masih belum penuh. Suatu hal yang menarik dari hasil penelitian ini adalah bahwa kebutuhan protein tersebut nampaknya tidak dipengaruh oleh ketersediaan energi. Konsumsi energi dalam penelitian ini meningkat secara signifikan $(\mathrm{P}<0.01)$ sehingga peningkatan suplai energi tersebut seharusnya meningkatkan potensi deposisi daging pada sapi Bali betina afkir yang selanjutnya akan meningkatkan kebutuhan protein. Pada kenyataannya hal ini tidak terjadi yang membuktikan bahwa kapasitas produksi daging sapi Bali betina afkir mungkin terbatas di kisaran hasil dalam penelitian ini. Sebelumnya (Jelantik et al., 2012) juga mendapatkan penambahan bahan pakan sumber karbohidrat pada pakan basal lamtoro ternyata menekan konsumsi komponen energi sedangkan dilain pihak konsumsi proteinnya meningkat. Peningkatan konsumsi protein ini mungkin dikarenakan ternak yang digunakan peneliti tersebut masih berada dalam usia produktif untuk memproduksi daging sehingga memiliki konsumsi protein yang meningkat. Sedangkan pada penelitian ini, ternak yang digunakan adalah sapi Bali betina afkir yang mana pertumbuhannya sudah tidak terjadi lagi.

Tabel 4. Pengaruh Pemberian Pakan Komplit Fermentasi Berbasis Daun Gamal Yang Mengandung Energi Metabolis sebesar $7 \mathrm{MJ} / \mathrm{kg}$ (EM7), $8 \mathrm{MJ} / \mathrm{kg}$ (EM8) dan 9 MJ/kg (EM9) Terhadap Kecernaan

\begin{tabular}{|c|c|c|c|c|c|}
\hline \multirow{2}{*}{ Parameter } & \multicolumn{3}{|c|}{ Perlakuan Level Energi } & \multirow{2}{*}{ SEM } & \multirow{2}{*}{$\mathrm{P}$} \\
\hline & EM7 & EM8 & EM9 & & \\
\hline \multicolumn{6}{|l|}{ Kecernaan $(\%)$ : } \\
\hline Bahan Kering & 68,03 & 67,71 & 70,33 & 0.70 & 0.28 \\
\hline Bahan Organik & 59,63 & 57,45 & 62,57 & 3.89 & 0.87 \\
\hline Protein Kasar & 58,61 & 59,48 & 60,15 & 4.56 & 0.99 \\
\hline Lemak Kasar & 84,66 & 89,41 & 90,58 & 1.42 & 0.23 \\
\hline Serat Kasar & 70,99 & 73,70 & 77,76 & 2.35 & 0.51 \\
\hline Karbohidrat & 60,57 & 57,52 & 63,49 & 3.72 & 0.81 \\
\hline BETN & 56,19 & 50,72 & 57,49 & 4.31 & 0.80 \\
\hline Energi metabolis (MJ) & 4,49 & 12,86 & 31,26 & 8.29 & 0.42 \\
\hline \multicolumn{6}{|c|}{ Konsumsi Nutrisi Tercerna (Kg/hari): } \\
\hline DDMI & 4,21 & 4,09 & 4,40 & 0.13 & 0.63 \\
\hline DOMI & 3,14 & 2,96 & 3,27 & 0.18 & 0.78 \\
\hline DCPI & 0,44 & 0,44 & 0,44 & 0.03 & 0.99 \\
\hline DEEI & $0,55^{\mathrm{a}}$ & $0,74^{\mathrm{b}}$ & $0,83^{\mathrm{b}}$ & 0.02 & 0.00 \\
\hline DCFI & 0,92 & 0,93 & 1,02 & 0.03 & 0.29 \\
\hline DCHO & 2,64 & 2,52 & 2,59 & 0.14 & 0.67 \\
\hline DCBETN & 1,72 & 1,52 & 1,74 & 0.12 & 0.70 \\
\hline DCEM & 0,84 & 5,39 & 15,06 & 4.23 & 0.39 \\
\hline
\end{tabular}

Ket : Superskrip yang berbeda menunjukan perbedaan yang nyata $(\mathrm{P}<0,05)$. DDMI : konsumsi bahan kering tercerna, DOMI : konsumsi bahan organik tercerna, DCPI : konsumsi protein tercerna, DEEI : konsumsi lemak tercerna, DCFI : konsumsi serat tercerna, DCHO: konsumsi karbohidrat tercerna, DBETN : konsumsi BETN tercerna

Kebutuhan sapi betina berat badan $200 \mathrm{~kg}$ dengan PBB 0,5-0,75 kg membutuhkan energi metabolis 10,20-12,05 Mcal atau setara dengan 41.8450,21 MJ. Sementara hasil penelitian ini mendapatkan rataan berat badan 180,81 $\mathrm{kg}$ dengan rataan $\mathrm{PBBH} 0,63 \mathrm{~kg}$ berdasarkan perhitungan kebutuhan energi metabolis sebesar 41,59 MJ. Oleh karena itu, nilai energi metabolis yang diperoleh dalam penelitian sebesar 49,00 MJ telah memenuhi kebutuhan energi metabolis ternak sapi Bali betina afkir.

Peningkatan level energi pakan ternyata tidak menyebabkan adanya perbedaan kecernaan bahan kering, level pakan yang kualitasnya baik (ditandai dengan tingginya kandungan protein dan rendah serat) ternyata tidak menyebabkan perubahan yang nyata terhadap kecernaan bahan kering. Hasil analisis statistik menunjukkan bahwa level energi pakan komplit fermentasi berbasis daun gamal tidak berpengaruh terhadap kecernaan serat kasar sapi Bali betina afkir $(\mathrm{P}>0,05)$. Nilai kecernaan serat kasar berkisar antara 70,99-77,76\% dengan rataan $74,15 \%$. Rentangan nilai KcSK pada penelitian ini tertinggi pada ternak yang mendapatkan perlakuan pakan EM9 MJ/kgBK (77,76\%), diikuti pakan perlakuan EM8 MJ/kgBK $(73,70 \%)$ dan terendah pada ternak yang mendapatkan pakan perlakuan EM7 MJ/kgBK. Hasil penelitian ini lebih tinggi dari laporan (Antonius, 2010) mendapatkan nilai KcSK pada ternak sapi yang mendapatkan pakan konsentrat dan jerami padi fermentasi sebesar 41,11$50,94 \%$. Ada beberapa hal yang memungkinkan tidak adanya perbedaan yang signifikan; kandungan protein untuk setiap perlakuan sama den juga berhubungan dengan ukuran partikel sumber serat dalam ransum pakan komplit fermentasi. Jerami padi fermentasi yang digunakan dalam penelitian ini terlebih dahulu sudah dicacah $3-5 \mathrm{~cm}$. Perlakuan pencacahan dapat memperluas permukaan pakan sehingga mempermudah mikroba rumen untuk mencerna pakan. Ukuran partikel yang relatif sama ini selanjutnya akan berhubungan dengan aktivitas mikroba yang sama dalam mencerna pakan untuk semua perlakuan. Proses pencacahan mengakibatkan ukuran partikel pakan lebih kecil sehingga ketika dikonsumsi ternak maka permukaan pakan menjadi lebih luas sehingga kecernaan antar semua perlakuan tidak berbeda nyata. Perlakuan pencacahan akan memperluas area permukaan pakan sehingga akan mempermudah mikroba untuk mencerna pakan. Hal berikut diakibatkan karena pakan yang diberikan merupakan ransum pakan komplit terfermentasi sehingga semua pakan memiliki potensi tercerna yang sama. Pada penelitiannya, (Mali, 2013) melaporkan bahwa faktor yang mempengaruhi tingginya kandungan nutrisi yang dicerna adalah tingginya kandungan BETN. Konsumsi BETN dalam penelitian ini relatif sama antar perlakuan dengan nilai rata-rata $3,19 \mathrm{~kg} / \mathrm{har}$ sehingga kecernaan yang dihasilkan antar perlakuan juga tidak berbeda nyata karena berhubungan dengan populasi mikroba dalam mencerna serat. Semakin tinggi kandungan BETN akan memberikan keuntungan bagi mikroba rumen untuk meningkatkan perkembangbiakan diri sehingga dapat meningkatkan kemampuan kecernaan serat

Tabel 5. Pengaruh Pemberian Pakan Komplit Fermentasi Berbasis Daun Gamal Yang Mengandung Energi Metabolis sebesar $7 \mathrm{MJ} / \mathrm{kg}$ (EM7), $8 \mathrm{MJ} / \mathrm{kg}$ (EM8) dan 9 MJ/kg (EM9) Terhadap PBB dan Konversi Pakan

\begin{tabular}{|c|c|c|c|c|c|}
\hline \multirow[t]{2}{*}{ Parameter } & \multicolumn{3}{|c|}{ Perlakuan Level Energi } & \multirow[t]{2}{*}{ SEM } & \multirow[t]{2}{*}{$\mathrm{P}$} \\
\hline & EM7 & EM8 & EM9 & & \\
\hline $\mathrm{PBE}$ & 0,52 & 0,63 & 0,75 & 0,05 & 0.08 \\
\hline $\begin{array}{l}\text { Konversi ransum (kg } \\
\text { BK/kg ADG) }\end{array}$ & 15,39 & 10,37 & 9,15 & 1,28 & 0,14 \\
\hline
\end{tabular}

Adanya kecenderungan peningkatan PBBh dalam penelitian ini mampu menggambarkan potensi PBBH pada sapi Bali betina afkir, namun nampak jelas bahwa kemampuan betina afkir untuk menghasilkan daging nampaknya mendekati atau sama dengan ternak jantan. Dari berbagai hasil penelitian yang telah dilakukan di NTT, PBB yang dicapai oleh ternak sapi jantan dalam penggemukan bervariasi dari rata-rata $300 \mathrm{~g}-460 \mathrm{~g}$ per hari (Bamualim dan Wirdahayati, 2003) pada ternak yang digemukkan menggunakan hijauan.Hal ini membuktikan bahwa betina afkir dapat digemukkan dengan hasil PBB yang memadai. Apabila dibandingkan dengan penggemukan ternak sapi jantan, PBB yang diperoleh pada penelitian ini tidak kalah jauh berbeda. Sapi betina afkir yang hanya diberikan daun lamtoro dan sedikit jerami padi mampu bertumbuh hingga $0,5 \mathrm{~kg}$ per hari (Jelantik et al., 2009). Sementara PBB yang diperoleh dalam penelitian ini lebih tinggi dari penelitian (Jelantik et al., 2012) dengan pemberian pakan pada kandungan protein kasar 12,3\% diperoleh PBB berkisar antara 0,48-0,57 (kg/hari). Kenyataan ini membuktikan bahwa sapi Bali betina afkir mempunyai potensi besar sebagai penghasil daging terutama untuk kebutuhan lokal. Dengan kapasitas PBB mencapai $0,75 \mathrm{~kg}$ per hari maka sebanyak 44,92 kg tambahan berat badan yang dapat diperoleh.

\section{Simpulan}

Dapat disimpulkan bahwa pemberian pakan komplit fermentasi berbasis daun gamal dengan level energi metabolis berbeda (EM 7 MJ/Kg BK, EM 8 $\mathrm{MJ} / \mathrm{Kg}$ BK dan EM $9 \mathrm{MJ} / \mathrm{Kg} \mathrm{BK}$ ) tidak mempengaruhi konsumsi dan kecernaan ternak sapi Bali betina afkir dan hasilnya cukup tinggi, dengan demikian dapat meningkatkan kecernaan bahan kering, protein kasar, energy metabolis, konsumsi bahan kering tercerna, konsumsi nutrien kemudian juga cenderung meningkatkan PBB sapi Bali betina afkir yang digemukan dengan protein kasar $12,3 \%$, dari pakan EM $8 \mathrm{MJ} / \mathrm{kgBK}$ menjadi EM $9 \mathrm{MJ} / \mathrm{kgBK}$ cenderung meningkatkan PBBHnya sebesar 0,63-0,75kg/hari.

\section{Pustaka}

Antonius, 2010. Pengaruh Pemberian Jerami Padi Terfermentasi Terhadap Palatabilitas Kecernaan Serat Dan Digestible Energy Ransum Sapi. 
http://lolitkambing.litbang.pertanian.go.id, Seminar Nasional Teknologi Peternakan dan Veteriner 2010.

Asngad, A., 2005. Perubahan Kadar Protein pada Fermentasi Jerami Padi dengan Penambahan Onggok Untuk Makanan Ternak. J. Penelit. Sains Teknol. 6: 65-74.

Bamualim, A., Wirdahayati, R.B., 2003. Nutrition and Management Strategis to Improve Bali Cattle productivity in Nusa Tenggara. ACIAR Proc. No. 110.pp. 17-22.

Dinas Peternakan NTT, 2013. Statistik Peternakan Propinsi NTT.

Jelantik, I.G.N., Malelak, G.E.M., Denoratu, R., 2012. Peningkatan Produksi dan Kualitas Daging Sapi Betina Afkir Melalui Pemberian Pakan Komplit Berbasis Pakan Lokal.

Jelantik, I.G.N., Manggol, Y.H., Jegho, J., Kune, P., Kleden, M., Leo Penu, C.L.O., Rosdiana Denoratu, M., Jermias, J.A., 2010. Mutu Genetik Sapi Timor di Nusa Tenggara Timur.

Jelantik, I.G.N., Mullik, M.L., Copland, R., 2009. Cara Praktis Menurunkan Angka Kematian dan Meningkatkan Pertumbuhan Pedet Sapi Timor Melalui Pemberian Pakan Suplemen.

Mali, O.Y.L., 2013. Pengaruh Umur Ternak dan Level Protein Konsentrat terhadap Konsentrasi VFA, Ammonia dan pH Rumen Sapi Bali Betina Afkir Penggemukan (Skripsi). Nusa Cendana, Kupang.

Mullik, M.L., Jelantik, I.G.N., 2009. Strategi Peningkatan Produktivitas Sapi Bali Pada Sistem Pemeliharaan Ekstensif Di Daerah Lahan Kering: Pengalaman Nusa Tenggara Timur.

Paraksasi, A., 1999. Ilmu Nutrisi dan Makanan Ternak Ruminan. Universitas Indonesia Press, Jakarta.

Preston, T.R., Leng, R.A., 1987. Matching Ruminant Production Sistems with Available Resources in the Tropic and Sub-Tropic. Int. Colour Prod., Stanthorpe, Queensland, Australia. 